\title{
Burkholone, A New Cytotoxic Antibiotic against IGF-I Dependent Cells from Burkholderia sp.
}

\author{
Toshiya Mori, Tomoki Yamashita, Kazuo Furihata, Koji Nagai, Ken-ichi Suzuki, \\ Yoichi Hayakawa, Kazuo Shin-ya
}

Received: June 6, 2007 / Accepted: October 22, 2007

(C) Japan Antibiotics Research Association

\begin{abstract}
In the course of our screening program for new inhibitors of IGF-I signaling, we isolated a new cytotoxic antibiotic, burkholone, from the culture broth of Burkholderia sp. QN15488. The structure of burkholone was determined to be (E)-3-methyl-2-(2-octenyl)-4quinolone by a series of NMR analyses. Burkholone induced cell death $32 \mathrm{D} / \mathrm{GR} 15$ cells with an $\mathrm{IC}_{50}$ value of $160 \mathrm{nM}$ in IGF-I containing medium, while no cell death was observed in IL-3 containing medium even at the concentration of $37 \mu \mathrm{M}$.
\end{abstract}

Keywords burkholone, insulin-like growth factor, quinolone, cytotoxic antibiotic

Insulin-like growth factors (IGFs) play in part a key role in human cancer progression. IGF signals through IGF-I receptor are known to be significant for tumor cell growth and survival [1]. Thus, inhibitors of IGF signal transduction are expected to be promising drugs for cancer chemotherapy. To evaluate the anti-IGF activity, we employed IGF-I receptor harboring 32D/GR15 cells which were derived from hematopoietic cell line $32 \mathrm{D}$ cells by transformed with the IGF-I receptor [2]. Viability and proliferation of 32D/GR15 cells are strictly dependent on cytokines such as interleukin-3 (IL-3). The IL-3-dependent 32D/GR15 cells undergo rapid apoptosis in the absence of IL-3. However, 32D/GR15 cells completely survive in an IL-3-free medium containing IGF-I [2]. Using $32 \mathrm{D} / \mathrm{GR} 15$ cells enables to distinguish the survival signaling between IL-3 and IGF-I [2]. In the course of our screening program for new inhibitors of IGF-I signaling, a new quinolone compound, (E)-3-methyl-2-(2-octenyl)-4quinolone designated as burkholone (1, Fig. 1) was isolated from the culture broth of Burkholderia sp. QN15488.

In this paper, we report the production, isolation, physico-chemical properties, structure elucidation and brief biological properties of $\mathbf{1}$.

Strain QN15488 was isolated from a soil sample

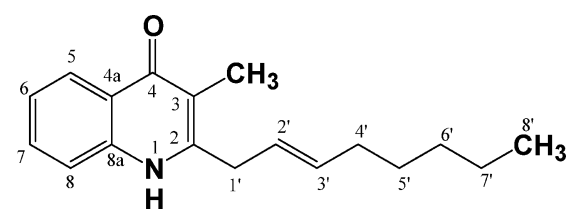

Fig. 1 Structure of burkholone (1).
K. Shin-ya (Corresponding author): Biological Information Research Center (BIRC), National Institute of Advanced Industrial Science and Technology (AIST), 2-42, Aomi, Koto-ku, Tokyo 135-0064, Japan, E-mail: k-shinya@aist.go.jp

T. Mori: Somatech Center, House Foods Corporation, 1-4, Yotsukaido, Chiba 284-0033, Japan

T. Yamashita: Institute of Molecular and Cellular Biosciences, The University of Tokyo, Bunkyo-ku, Tokyo 113-0032, Japan
K. Furihata: Department of Applied Biological Chemistry, The University of Tokyo, Bunkyo-ku, Tokyo 113-8657, Japan

K. Nagai: Fermentation Research Labs., Astellas Pharma Inc., 5-2-3, Toukoudai, Tsukuba-shi, Ibaraki 305-2698, Japan

K. Suzuki: Astellas Research Service Co., Ltd., Astellas Pharma Inc., 21, Miyukigaoka, Tsukuba-shi, Ibaraki 305-8585, Japan

Y. Hayakawa: Faculty of Pharmaceutical Sciences, Tokyo University of Science, 2641, Yamazaki, Noda-shi, Chiba 2788510, Japan 
Table 1 Physico-chemical properties of burkholone (1)

\begin{tabular}{ll}
\hline Appearance & White powder \\
MP & $218 \sim 220^{\circ} \mathrm{C}$ \\
Molecular formula & $\mathrm{C}_{18} \mathrm{H}_{23} \mathrm{NO}$ \\
HRFAB-MS $(\mathrm{m} / \mathrm{z})$ & \\
Found: & $270.1866(\mathrm{M}+\mathrm{H})^{+}$ \\
Calcd.: & $270.1858(\mathrm{M}+\mathrm{H})^{+}$ \\
UV $\lambda_{\max } \mathrm{nm}(\varepsilon)$ in $\mathrm{MeOH}$ & $335(7,400), 322(7,100)$, \\
IR $v_{\max }(\mathrm{KBr}) \mathrm{cm}^{-1}$ & $240(20,000), 212(17,000)$ \\
& $1730,1630,1610$
\end{tabular}

collected on Ishigaki island, Okinawa Prefecture, Japan. The partial 16S rDNA gene sequence of strain QN15488 showed high levels of identity with strains from the genus Burkholderia. The producing organism was inoculated into a seed medium consisting of glucose $1.0 \%$, potato starch $2.0 \%$, Polypepton $0.5 \%$, yeast extract $0.5 \%$ and $\mathrm{CaCO}_{3}$ $0.4 \%(\mathrm{pH} 7.0)$, and cultured on a rotary shaker at $28^{\circ} \mathrm{C}$ for 3 days. The seed culture was transferred to $500-\mathrm{ml}$ Erlenmeyer flasks each containing $100 \mathrm{ml}$ of a production medium composed of glucose $0.5 \%$, casamino acid $0.5 \%$, Polypepton $3.0 \%$, yeast extract $0.5 \%, \mathrm{Na}_{2} \mathrm{HPO}_{4} 0.5 \%$, $\mathrm{KH}_{2} \mathrm{PO}_{4} 0.1 \%, \mathrm{NH}_{4} \mathrm{Cl} 0.1 \%$ and $\mathrm{MgSO}_{4} \cdot 7 \mathrm{H}_{2} \mathrm{O} 0.05 \%(\mathrm{pH}$ 7.0). The fermentation was carried out at $28^{\circ} \mathrm{C}$ for 4 days on a rotary shaker.

The mycelial cake of the broth (10 liters) was extracted with acetone. The acetone extract was evaporated to an aqueous concentrate and then partitioned between ethyl acetate and water. The organic layer was evaporated in vacuo to dryness. The crude material $(900 \mathrm{mg}$ ) was subjected to silica gel column chromatography and developed with $\mathrm{CHCl}_{3}-\mathrm{MeOH}(90: 1)$. The active fraction was purified by HPLC using a Senshu-Pak PEGASIL ODS column (particle size: $7 \mu \mathrm{m}, 20$ i.d. $\times 250 \mathrm{~mm}$ ) with $70 \%$ $\mathrm{MeOH}$ to give a colorless powder of $\mathbf{1}(1.54 \mathrm{mg})$.

The physico-chemical properties of $\mathbf{1}$ are summarized in Table 1. The molecular formula of burkholone was established to be $\mathrm{C}_{18} \mathrm{H}_{23} \mathrm{NO}$ by high-resolution FAB-MS. The direct connectivity of protons and carbons was established by the HMQC spectrum and the tabulated ${ }^{13} \mathrm{C}$ and ${ }^{1} \mathrm{H}-\mathrm{NMR}$ spectral data for burkholone are shown in Table 2. The sequence from the methylene proton $\mathrm{H}-1^{\prime}$ $\left(\delta_{\mathrm{H}} 3.47\right)$ to a methyl proton $\mathrm{H}-8^{\prime}\left(\delta_{\mathrm{H}} 0.85\right)$ through $\mathrm{H}-2^{\prime}$ $\left(\delta_{\mathrm{H}} 5.50\right), \mathrm{H}-3^{\prime}\left(\delta_{\mathrm{H}} 5.62\right), \mathrm{H}-4^{\prime}\left(\delta_{\mathrm{H}} 2.00\right), \mathrm{H}-5^{\prime}\left(\delta_{\mathrm{H}} 1.32\right)$, H-6' $\left(\delta_{\mathrm{H}} 1.25\right)$ and H-7' $\left(\delta_{\mathrm{H}} 1.27\right)$ observed in the DQF spectrum revealed the presence of a 2-octene moiety (Fig. 2). In the same manner, a 1,2-disubstituted benzene substructure was also established by the correlations among aromatic protons $\mathrm{H}-5\left(\delta_{\mathrm{H}} 8.35\right), \mathrm{H}-6\left(\delta_{\mathrm{H}} 7.25\right), \mathrm{H}-7$
Table $2{ }^{1} \mathrm{H}$ - and ${ }^{13} \mathrm{C}$-NMR data of $\mathbf{1}$ in $\mathrm{CDCl}_{3}$

\begin{tabular}{|c|c|c|}
\hline No. & $\delta_{\mathrm{C}}$ & $\delta_{\mathrm{H}}$ (multiplicity, $J=\mathrm{Hz}$ ) \\
\hline 2 & 147.5 & \\
\hline 3 & 115.7 & \\
\hline 4 & 178.1 & \\
\hline $4 a$ & 123.6 & \\
\hline 5 & 126.0 & $8.35(\mathrm{dd}, J=8.0,1.0)$ \\
\hline 6 & 123.1 & $7.25(\mathrm{dt}, J=8.0,1.0)$ \\
\hline 7 & 131.1 & $7.50(\mathrm{dt}, J=8.0,1.0)$ \\
\hline 8 & 117.4 & $7.45(d, J=8.0)$ \\
\hline $8 a$ & 139.0 & \\
\hline $1^{\prime}$ & 35.5 & $3.47(2 \mathrm{H}, \mathrm{d}, J=7.0)$ \\
\hline $2^{\prime}$ & 123.1 & $5.50(d d t, J=15.0,7.0,1.0)$ \\
\hline $3^{\prime}$ & 136.0 & $5.62(d d t, J=15.0,7.0,1.0)$ \\
\hline $4^{\prime}$ & 32.5 & $2.00(2 \mathrm{H}, \mathrm{dd}, J=15.0,7.0)$ \\
\hline $5^{\prime}$ & 28.8 & $1.32(2 \mathrm{H}, \mathrm{m})$ \\
\hline $6^{\prime}$ & 31.4 & $1.25(2 \mathrm{H}, \mathrm{m})$ \\
\hline $7^{\prime}$ & 22.5 & $1.27(2 \mathrm{H}, \mathrm{m})$ \\
\hline $8^{\prime}$ & 14.0 & $0.85(3 \mathrm{H}, \mathrm{t}, J=7.0)$ \\
\hline 3-Me & 10.5 & $2.15(3 \mathrm{H}, \mathrm{s})$ \\
\hline $1-\mathrm{NH}$ & & 10.12 (br s) \\
\hline
\end{tabular}

${ }^{13} \mathrm{C}$ - and ${ }^{1} \mathrm{H}-\mathrm{NMR}$ spectra were recorded at $125 \mathrm{MHz}$ and $500 \mathrm{MHz}$, respectively.

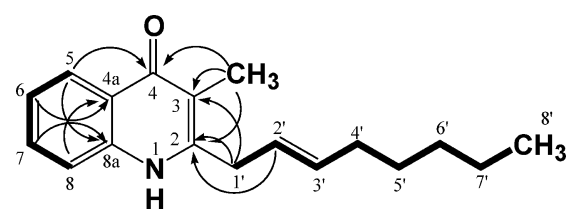

Fig. 2 COSY and HMBC analyses for 1. Bold lines show proton spin networks and arrows indicate ${ }^{1} \mathrm{H}-{ }^{13} \mathrm{C}$ long-range correlations.

$\left(\delta_{\mathrm{H}} 7.50\right)$ and $\mathrm{H}-8\left(\delta_{\mathrm{H}} 7.45\right)$ (Fig. 2$)$. The heteronuclear multiple-bond correlation (HMBC) spectrum displayed the long-range ${ }^{1} \mathrm{H}^{13}{ }^{13} \mathrm{C}$ couplings from a methyl proton $\left(\delta_{\mathrm{H}} 2.15,3-\mathrm{CH}_{3}\right)$ to $\mathrm{C}-2\left(\delta_{\mathrm{C}} 147.5\right), \mathrm{C}-3\left(\delta_{\mathrm{C}} 115.7\right)$ and a carbonyl carbon C-4 $\left(\delta_{\mathrm{C}} 178.1\right)$, which was in turn longrange coupled to $\mathrm{H}-5\left(\delta_{\mathrm{H}} 8.35\right)$. A methylene proton $\mathrm{H}-1^{\prime}$ ( $\delta_{\mathrm{H}} 3.47$ ) was long-range coupled to $\mathrm{C}-2$ and $\mathrm{C}-3$. Thus, the 2-octene and methyl residues were revealed to be substituted at the $\mathrm{C}-2$ and $\mathrm{C}-3$ position, respectively. Longrange ${ }^{1} \mathrm{H}-{ }^{13} \mathrm{C}$ couplings on the benzene ring moiety established the assignment of the remaining aromatic carbons C-4a $\left(\delta_{\mathrm{C}} 123.6\right)$ and $\mathrm{C}-8 \mathrm{a}\left(\delta_{\mathrm{C}} 139.0\right)$ as shown in Fig. 2. By taking into consideration the molecular formula of $1, \mathrm{C}-2$ and C-8a should be connected through a nitrogen atom. The geometrical configuration of $\mathrm{C}-2^{\prime}$ was proved to 


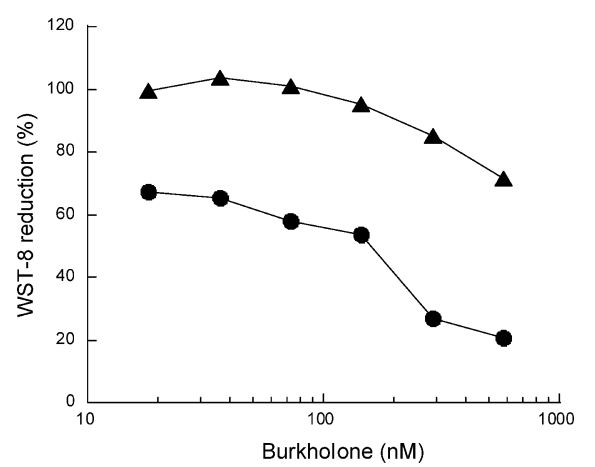

Fig. 3 Effects of $\mathbf{1}$ on the viability and growth of 32D/GR15 cells.

ム, IL-3; •, IGF-I. 32D/GR15 cells were cultured for 36 hours with various concentrations of $\mathbf{1}$ and then the survival was measured by the WST-8 assay.

be $E$ by a large coupling constant $\left(J_{2^{\prime} \mathrm{H}-3^{\prime} \mathrm{H}}=15.0 \mathrm{~Hz}\right)$. The correspondence of ${ }^{13} \mathrm{C}$ chemical shifts assigned to the chromophore moiety between $\mathbf{1}$ and quinolone compounds such as PSC-D, YM-30059 and CJ-13,136 strongly supported the structure of 1 [3 5]. Thus, the structure of 1 was established to be (E)-3-methyl-2-(2-octenyl)-4quinolone as shown in Fig. 2.

32D/GR15 cells were cultured for 36 hours with various concentrations of $\mathbf{1}$ and then the survival was measured by WST-8 [2-(2-methoxy-4-nitrophenyl)-3-(4-nitrophenyl)5-(2,4-disulfophenyl)-2 $H$-tetrazolium monosodium salt] assay. 1 induced cell death in 32D/GR15 cells in the IL-3free medium containing IGF-I $(50 \mathrm{ng} / \mathrm{ml})$ with an $\mathrm{IC}_{50}$ value of $160 \mathrm{nM}$. Contrary to the potent cytotoxicity in IL-3 free medium, burkholone did not exhibit cytotoxic activity in IL-3 ( $2 \mathrm{ng} / \mathrm{ml})$ containing medium ( $\mathrm{IC}_{50}>37 \mu \mathrm{M}$, Fig 3$)$. Several human cancer cells were cultured for 72 hours with various concentrations of $\mathbf{1}$ and then the survival was measured by MTT [3-(4,5-dimethylthiazol-2-yl)-2,5diphenyltetrazolium bromide] assay. 1 also induced cell death to IGF-I high dependent MCF-7 [6] human breast cancer cells ( $\mathrm{IC}_{50} 240 \mathrm{nM}$ ) and IGF-I low dependent HeLa [6] human cervical cancer cells $\left(\mathrm{IC}_{50} 140 \mathrm{nM}\right)$. Such activity of $\mathbf{1}$ was not observed in IGF-I low dependent HT1080 human fibrosarcoma cells ( $\left.\mathrm{IC}_{50} 15 \mu \mathrm{M}\right)$ and IGF-I low dependent $\mathrm{SiHa}$ [7] human cervical cancer cells $\left(\mathrm{IC}_{50}\right.$ $>37 \mu \mathrm{M}$ ). Expression of antisense RNA directed against the IGF-IR mRNA lowers the expression of the IGF-IR in MCF-7cells, HeLa cells and SiHa cells and slightly inhibits their growth $[6,7]$. These findings suggested that 1 induced cell death not only by direct action on IGF-I-dependent pathway but also involves other action mechanism. Although, some kinase inhibitors of IGF-IR were reported $[8,9]$, there is only one report that synthetic quinolones possessed inhibitory effects against EGFR tyrosine kinase [10]. Quinolones are reported to show antitumor effects targeting DNA related factors such as topoisomerases I and II [11 15]. A variety of 3-methyl-2-alkenyl-4quinolones shows antibacterial activities against Grampositive bacteria [16], including multiple-drug resistant Staphylococcus aureus and S. epidermidis [4], plant growth promoting activities and antifungal activities [3]. But $\mathbf{1}$ did not induce antibacterial activity against Bacillus subtilis at $370 \mu \mathrm{M}$. Further biological studies on $\mathbf{1}$ are now under way.

Acknowledgements We are grateful to Dr. Renato Baserga (Kimmel Cancer Center, Thomas Jefferson University) for providing 32D/GR15 cells. This work was supported by New Energy and Industrial Technology Development Organization (NEDO) of Japan.

\section{References}

1. Baserga R, Hongo A, Rubini M, Prisco M, Valentinis B. The IGF-I receptor in cell growth, transformation and apoptosis. Biochim Biophys Acta 1332: F105-F126 (1997)

2. Peruzzi F, Prisco M, Dews M, Salomoni P, Grassilli E, Romano G, Calabretta B, Baserga R. Multiple signaling pathways of the insulin-like growth factor I receptor in protection from apoptosis. Mol Cell Biol 19: 7203-7215 (1999)

3. Moon S, Kanga PM, Park KS, Kim CH. Plant growth promoting and fungicidal 4-quinolinones from Pseudomonas cepacia. Phytochemistry 42: 365-368 (1996)

4. Kamigiri K, Tokunaga T, Shibazaki M, Setiawan B, Rantiatmodjo RM, Morioka M, Suzuki K. YM-30059, a novel quinolone antibiotic produced by Arthrobacter sp. J Antibiot 49: 823-825 (1996)

5. Dekker KA, Inagaki T, Gootz TD, Huang LH, Kojima Y, Kohlbrenner WE, Matsunaga Y, McGuirk PR, Nomura E, Sakakibara T, Sakemi S, Suzuki Y, Yamauchi Y, Kojima N. New quinolone compounds from Pseudonocardia sp. with selective and potent anti-Helicobacter pylori activity: taxonomy of producing strain, fermentation, isolation, structural elucidation and biological activities. J Antibiot 51: 145-152 (1998)

6. Neuenschwander S, Roberts CT Jr, LeRoith D. Growth inhibition of MCF-7 breast cancer cells by stable expression of an insulin-like growth factor I receptor antisense ribonucleic acid. Endocrinology 136: 4298-4303 (1995)

7. Nakamura K, Hongo A, Kodama J, Miyagi Y, Yoshinouchi M, Kudo T. Down-regulation of the insulin-like growth factor I receptor by antisense RNA can reverse the transformed phenotype of human cervical cancer cell lines. Cancer Res 60: 760-765 (2000)

8. Parrizas M, Gazit A, Levitzki A, Wertheimer E, LeRoith D. Specific inhibition of insulin-like growth factor-1 and 
insulin receptor tyrosine kinase activity and biological function by tyrphostins. Endocrinology 138: 1427-1433 (1997)

9. Garcia-Echeverria C, Pearson MA, Marti A, Meyer T, Mestan J, Zimmermann J, Gao J, Brueggen J, Capraro HG, Cozens R, Evans DB, Fabbro D, Furet P, Porta DG, Liebetanz J, Martiny-Baron G, Ruetz S, Hofmann F. In vivo antitumor activity of NVP-AEW541-A novel, potent, and selective inhibitor of the IGF-IR kinase. Cancer Cell 5: 231-239 (2004)

10. Traxler P, Green J, Mett H, Séquin U, Furet P. Use of a pharmacophore model for the design of EGFR tyrosine kinase inhibitors: isoflavones and 3-phenyl-4(1H)quinolones. J Med Chem 42: 1018-1026 (1999)

11. Robinson MJ, Martin BA, Gootz TD, McGuirk PR, Osheroff N. Effects of novel fluoroquinolones on catalytic activities of eukaryotic topoisomerase II: Influence of the C-8 fluorine group. Antimicrob Agents Chemother 36: 751-756 (1992)

12. Kohlbrenner WE, Wideburg N, Weigl D, Saldivar A, Chu DT. Induction of calf thymus topoisomerase II-mediated DNA breakage by antibacterial isothiazoloquinolones A65281 and A-65282. Antimicrob Agents Chemother 36: 81-86 (1992)
13. Wentland MP, Lesher GY, Reuman M, Gruett MD, Singh B, Aldous SC, Dorff PH, Rake JB, Coughlin SA. Mammalian topoisomerase II inhibitory activity of 1-cyclopropyl-6,8difluoro-1,4-dihydro-7-(2,6-dimethyl-4-pyridinyl)-4-oxo-3quinolinecarb oxylic acid and related derivatives. J Med Chem 36: 2801-2809 (1993)

14. Tomita K, Tsuzuki Y, Shibamori K, Tashima M, Kajikawa F, Sato Y, Kashimoto S, Chiba K, Hino K. Synthesis and structure-activity relationships of novel 7-substituted 1,4-dihydro-4-oxo-1-(2-thiazoly1)-1,8-naphthyridine-3carboxylic acids as antitumor agents. Part 1. J Med Chem 45: 5564-5575 (2002)

15. Tsuzuki Y, Tomita K, Shibamori K, Sato Y, Kashimoto S, Chiba K. Synthesis and structure-activity relationships of novel 7-substituted 1,4-dihydro-4-oxo-1-(2-thiazolyl)-1,8naphthyridine-3-carboxylic acids as antitumor agents. Part 2. J Med Chem 47: 2097-2109 (2004)

16. Hays EE, Wells IC, Katzman PA, Cain CK, Jacobs FA, Thayer SA, Doisy EA, Gaby WL, Roberts EC, Muir RD, Carroll CJ, Jones LR, Wade NJ. Antibiotic substances produced by Psedomonas aeruginosa. J Biol Chem 159: 725-749 (1945) 